\title{
Predictors Of Consumers' Choice Of Buying Outlets In Imo And Abia States, Nigeria
}

\author{
Chukwuemeka A. Onyeagwara \\ Department of Marketing, \\ Federal Polytechnic, Nekede, Nigeria \\ Godswill A. Agu \\ Department of Marketing, \\ Abia State University, Uturu, Nigeria \\ Ebeke Egele Aja \\ Department of Marketing, \\ Ebonyi State University, Abakaliki, Nigeria
}

\begin{abstract}
This study examines the predictors of consumer choice of buying outlet using shoppers in Imo and Abia States. The predictors were modeled as outlet attributes, demographic attribute and product attribute. A sample size of 272 was used for the study while questionnaire served as the data collection instrument. Stated hypotheses were tested with multiple regression analysis in SPSS version 20. Findings revealed that the three predictors (product, outlet and demographic attributes) are significant predictors of choice of buying outlets by consumers. Further analysis however showed that parking space and price which are variables under outlet and product attributes respectively are not significant predictors of choice of shopping outlet. The study recommended among others that shop owners and managers should monitor closely the variables disclosed as significant predictors while striving to adopt the conceptual model of predictors presented in this work.
\end{abstract}

\section{INTRODUCTION}

The perplexity of the buying decisions and behaviours of consumers have remained a source of worry to marketers as such decisions and behaviours most times, are not accurately predicted by marketing organizations. These decisions and their relative behaviours are not just on the choice of product brands but also on the choice of buying (retail) outlets (Jobber, 2009; Oghojafor \& Nwagwu, 2013). Meng, Florkowski, Chinan and Resurrection (2014) noted that consumers' decisions on buying outlets are on three alternative shopping outlets: supermarkets, open-air market and hawking. Before now as rightly observed by Riaz and Mazhar (2015), consumers mainly focused on product features and attributes to opt for a shopping place. Today, however, many more factors influence choice of buying outlets.

Hawkins, Best and Covey (2001) outlined some evaluation criteria used by consumers to select an outlet. These criteria include: image, advertising, location and size. The outlet image according to them is further defined with merchandise, service, physical facilities, convenience, promotion, store atmosphere, reputation and satisfaction. Salfulla (2015) identified price, product quality, trust and experience as key factors, while Medna and Ward (1999) modeled price, purchase size and demographics as predictors of choice of buying outlet for beef. In merchandise, Chamhuri and Bertt (2014) identified price, product quality, product varieties, pleasant environment, convenience and good relationship as key drivers of outlet choice. 
The evolving nature of retailing and its various forms; and the consequent competitiveness in the sector has frequently held the interest of scholars. Thus, Kautman and Lane (1996) and Fasquet, Gil and Molle, Parikh (2006) and Oghojafor et al (2012) noted that today's global retail environment is rapidly changing more than ever before as it is limited by growing competition from both domestic and foreign companies, a rise in mergers and acquisitions, and more classy and demanding customers who have great expectations related to their consumption experiences. In addition to this is the increasing adoption of e-marketing platforms. The changes have significant impact on the buying decisions and shopping behaviour of consumers (Arnond, Price \& Zinkhan, 2002; North \& Kotze, 2004; Silutman \& Kank, 2004). With the recent changes in the Nigerian economy and general business/marketing environment, there is an urgent need to empirically study the buying outlet decisions of Nigerian consumers and factors influencing such decisions.

\section{Statement of the Problem}

Studies in the retail sector of developing countries have been scarce (Khare, 2016; Oghojafor et al, 2012). Most studies in this area of global importance are Western or developed countriesbased. Literatures on the buying outlets decisions of developing countries' consumers are necessary for investment decisions of organizations and formulation of strategic marketing programmes. Reviewed literatures proved that previous researchers concentrated on single products such as beef, fish, etc. others used only one category of outlet decision predictors (e.g. demographics) or comparing consumer's behaviour in only two forms of buying outlets (e.g. open-markets and supermarkets).

This study is an empirical research which uses a four-factor model conceptually developed for the study. The study unlike the studies of previous scholars categorized predictors of consumers' choice of shopping outlets into three: outlet attributes, demographics, product attributes and e-marketing attributes. Each of these predictors has sub-variables that would be measured in the study. Again, the shopping outlet alternatives to be covered in the study are: the open-market, supermarkets and hawking. This is unlike previous studies that concentrated on one or two of these four.

\section{Objectives of the Study}

The primary aim of this paper is to provide additional perception and empirical evidence regarding consumers' shopping tendencies measuring the key predictors of buying outlet decision. Specifically, the following objectives would be achieved:

i. To ascertain the nature of relationship between outlet attributes and choice of buying outlet.

ii. To ascertain the nature of relationship between demographic attributes and choice of buying outlet.

iii. To ascertain the nature of relationship between product attributes and choice of buying outlet.

\section{Scope of the Study}

The geographical setting of this research study is Imo and Abia States, with specific attention on Owerri and Umuahia. This study was domiciled in the area of consumer behaviour with major emphasis on choice and buying behaviour. The units of analysis in the study were the customers of retail outlets in the city that are in open-market, supermarkets and hawking shopping outlet alternatives. 


\section{CONCEPTUAL REVIEW}

An outlet is a shop or organization which sells the goods made by a particular manufacturer. In other words, a shopping outlet is a brick and mortar or online store in which manufacturers sell their stock directly to the public, cutting out the middle-men. Meng, Florkowski, Sarpong, Chinnan and Resurreccion (2014) identified three alternative shopping outlet types to include: supermarket, open-air market, and hawking.

\section{Supermarkets}

McClelland's (1962) definition as contained in Meng et al (2014) states that supermarkets are large self-service food shops. Supermarket typically implies a larger grocery store owned by an independent proprietor. It also includes some large chain stores located in shopping centres. Supermarkets sell a wide variety of products such as dry goods, meats, bakery items, beverages, frozen foods, dairy products, and non-food goods, and provide food-processing services.

In Nigeria, supermarkets sell high-quality organic and natural foods including freshly prepared meats, baked bread, and garden fresh produce, while a large number of products are imported. Currently, the domestically owned supermarkets dominate the supermarket sector. In Owerri for instance, such supermarkets as Cyril, Destiny, Pick N Smile, Johny etc have stood the test of time, having sold reliable and quality products to the consumers. Shop Rite, a gigantic retail outlet that emphasizes quality, affordability, convenience and availability at all time started operation in the city two years ago. Also, in Abia State we have Royal, Freedom and Capital Supermarkets.

\section{The open-air market}

The open-air market is a public marketplace selling food and merchandise. Some open-air markets in Nigeria operate every day, while others follow some patterns. Most goods sold there are of domestic origin or locally produced foods, including fresh vegetables, fruits, and meat. Although open-air markets lack cold storage facilities and proper protection of product freshness, they appeal to buyers with competitive prices and travel convenience. In the recent decades, however, most of the ancient open air markets have metamorphosed into modern, national and international markets with averagely good facilities, security, power and availability of all sorts of goods at competitive prices. For instance, Ariara International Market Aba, Onitsha Main Market, Ekeonuwa Market in Owerri etc.

\section{Hawking}

Hawkers are persons travelling through towns and neighbourhoods to sell goods. In large cities, they usually occupy major street intersections. Most foods sold by hawkers are ready-toeat or prepared food products for on-site consumption. In Nigeria and most West African countries, hawkers are still a necessary part of the food retail system. Street hawking is both time and cost effective for consumers, since transactions can occur through buyer car windows, avoiding the potential troublesome travel to markets. Because of a lack of knowledge, education, and regulation, food sold by hawkers is potentially a source of public health problems due to microbial contamination (Toh and Birchenough 2000). In some states in Nigeria, hawking is frowned at by government authorities, though hawkers defy all attempts to stop them.

\section{Predictors of Consumer Choice of Buying Outlets}

Having reviewed relevant theories, empirical studies and literatures on key predictors of consumer choice of buying outlets, the researcher discovers that there is no known model of 
consumer buying outlets predictors. However, research has shown that certain variables are common among the studies of researchers. Also, it was discovered that there is no known study of this nature covering consumers in the eastern part of Nigeria and Abia/Imo in particular. Most studies focus on a particular product, a particular gender or a particular buying outlet. This present study is set to fill these gaps by developing a conceptual framework that could be developed into a model of predictors of consumer choice of buying outlets. To achieve this, the study will focus on three key predictors with their various sub-variables. These are:

i. Outlet Variables: these refer to factors surrounding the buying outlet in terms of location, neatness of environment, convenience in reach, parking space, quick shopping, etc.

ii. Demographic Factors: These are factors about the individual consumer in terms of gender, age, income level, occupation, family size, marital status, educational background, etc.

iii. Product Attributes: These are factors about the product to be purchased in terms of quality, price, availability of other brands, after sales services, etc. The diagram below shows the conceptual framework. 


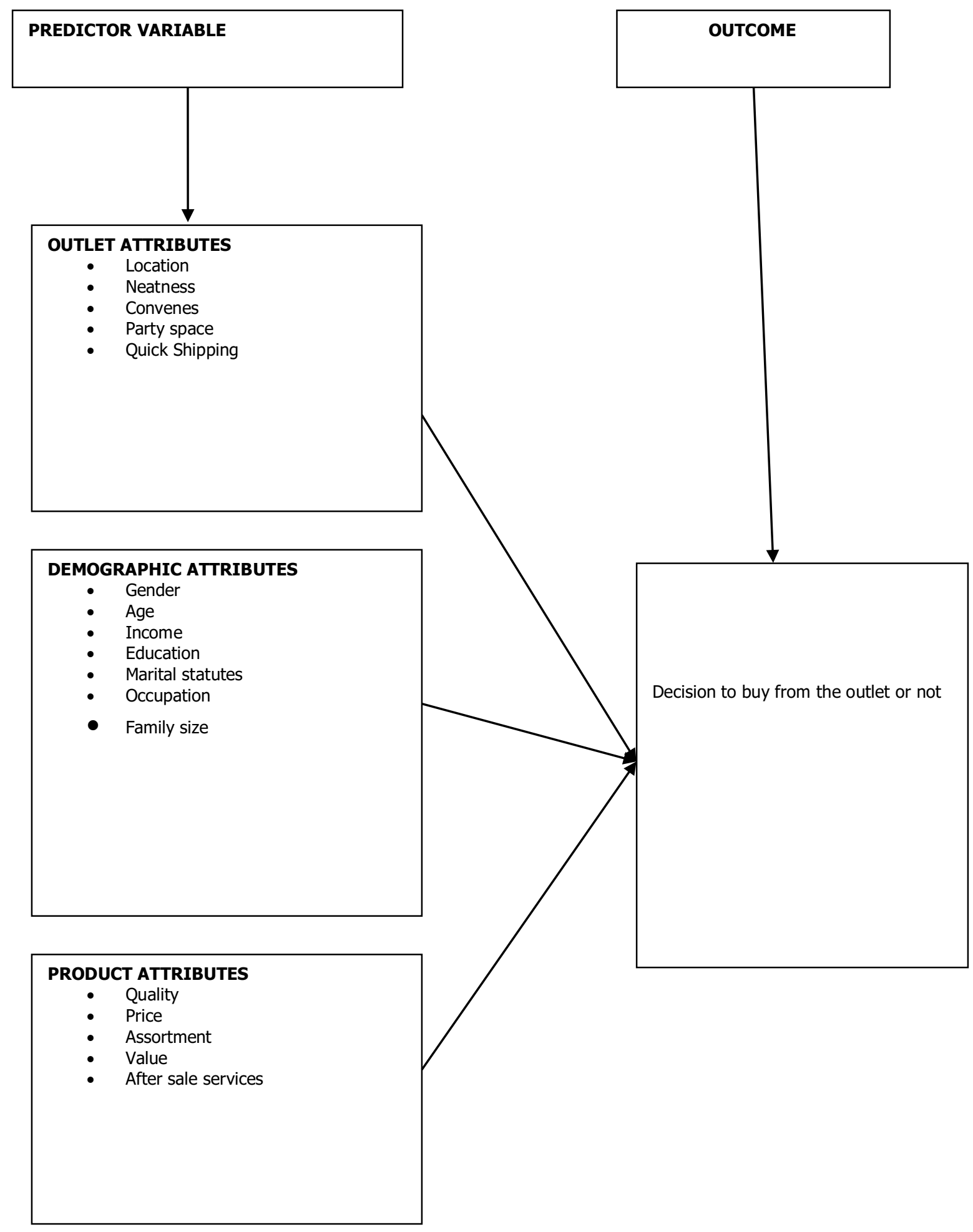

Source: Researchers' Conceptualization for the study (2015)

Studies on consumer behaviour revolve around these variables as a significant proportion of influences on buying outlet decisions hinge on them. Based on these, we hypothesized thus: $\mathbf{H O}_{1}$ : There is no significant relationship between outlet attributes and choice of buying outlet. $\mathbf{H O}_{2}$ : There is no significant relationship between demographic attributes and choice of buying outlet.

$\mathbf{H O}_{3}$ : There is no significant relationship between product attributes and choice of buying outlet. 


\section{THEORETICAL REVIEW}

This study examined the shopping behaviour of Nigerian consumers in Imo and Abia States from the perspective of attribution theory which many scholars have also used. Swanson and Kelley (2001) defined attribution theory as "a collection of several theories that are concerned with the assignment of causal inferences and how these interpretations influence evaluations and behaviour." In his view, Weiner (2000) observe that "Attributions play their role in postinitial outcome decision making; that is, attributions intervene and exert their influence after a product-related outcome and prior to the next choice. Attributions arise when one evaluates the extent to which the initial product performance corresponds to one's level of aspiration vis-a'-vis that product, and one then questions the cause of the outcome Oghojafor, et al (2012).

Attribution theory suggests that consumers' future shopping intentions depend on attributes such as personal budgets, which may restrict the consumer choice and ability to satisfy their wants and needs etc. By identifying the vital attributes that influence consumer decision making and shopping behaviour, marketers can refer to important attributes that are relevant to each of the market segments.

\section{Empirical Review}

A number of studies have been undertaken to ascertain the buying outlet predictors. Miranda, Konya and Havrila (2005) identified store attributes as multi dimensional construct including location of store, nature and quality of stocks, in-store promotions, sales personnel, physical attribute, and convenience of store, atmospherics and loyalty cards that influence consumer attitude or behaviour. Quality, price, availability of new products and product value are the product attributes that influence consumer attitude (Jin \& Kim, 2003).

Similarly, in another study, Yilmaz et al., (2007) found that for customers, the location of the shopping mall, product, price and quality, physical appearance, attitude of store staff were important factors shaping their outlet selection. Yalcin (2005) posit that such demographic factors as age, occupation and number of children affect supermarket loyalty. In their own study, Akinci et al. (2007) found that the most important factors that affect supermarket patronage in Istanbul are pricing, quality and waiting time at the cashier.

Again, Polat and Kulter (2007) found that the factors which determine customers' market and supermarket choices include product diversity, product quality, inner atmosphere and appearance, quick shopping facility, attitude and interest of staff, and prices of goods. In another study by Duman and Yagci (2006), it was discovered that customers' patronage intentions are affected by value perception, product quality perception, service quality perception, discount perception and comparable price perception. Yeniceri and Erten (2008) found that trust and commitment affect store loyalty. The quality of retailer service is generally assessed by customers to include the appearance of staff and their attentiveness, kindness, politeness, staff level of experience, safe shopping environment etc (Cronin et al., 2000).

In addition to the foregoing, special discounts and promotion were found to increase customers' interest toward the supermarket (Grewal et al., 1998). In another instance, perception of value and satisfaction were found to affect customers' attitude and store loyalty and intention to purchase (Grace \& O'Cass, 2005).

In India, Sinha and Banerjee (2004) found that store convenience and customer services positively influence customers' supermarket choices, whilst, entertainment, parking and ambience facilities had a negative influence on consumer outlet choices. Indian consumers 
were also found to be price sensitive and quality conscious (Tuli \& Mookerjee, 2004). Ling, Choo, \& Pysarchik (2004) note that Indian customers' attitude towards new products are changing significantly and this can increase their intention to shop in new retail outlets such as supermarkets. Thus, product attributes such as quality, price and availability of new products are important constructs within the Indian context.

As literature reveals a whole lot of studies have been undertaken to unravel store patronage behavior of consumers in the different regions of the world with consumers in the advanced countries of America and Europe enjoying centre stage. However, in recent times there seems to be a growing interest in consumer store preferences in the developing countries of Asia and Africa. Also a number of studies have been conducted in Turkey to determine customers' attitudes to and preferences for supermarkets, and store image perceptions and loyalty. In their own study, Akinci et al. (2007) found that the most important factors that affect supermarket patronage in Istanbul are pricing, quality and waiting time at the cashier.

Uslu's (2005) study in Turkey found that the approach of the store staff to customers, contents of products, packing space, issues of hygiene, after sales services, variety of products, product price, location convenience, and quality of products on offer are major factors impacting customers' choice of shopping centres. In a study to determine outlet attributes that influence Nigerian women's preference between a supermarket and the African traditional open market, Oghojafor, et al (2012) found that seven attributes were considered important by Nigerian women in making a choice of outlets. These attributes in order of importance were: quality, price, location of outlet, cleanliness, product assortment, pricing method, and availability of parking space.

Having reviewed these studies, it can be seen at a glance that very little studies have been carried out in the Nigerian context. The few that were conducted, for instance, Oghojafor, et al (2012), concentrated on women shopping behaviour. This shows that there are lots of gaps to be filled in this area of consumer behaviour study. To fill the identified gaps, this study will take a look at the effect of three key predictors (outlet attributes, demographic attributes and product attributes) on consumers' choice of buying outlets for grocery items. Our conceptual framework clearly shows the variables in each of the three key constructs.

\section{RESEARCH METHODOLOGY}

This study adopted the survey design. The study population consists of customers of openmarkets and supermarkets in Owerri. This shows that the population of the study is infinite. The Cochran (1963) formula for infinite population was applied to arrive at 272 as the sample size. The Likert structure was used to form the questionnaire. Using the responses of 20 respondents who were issued the questionnaire on a pilot test, table 1 shows the result of the Cronbach's alpha test and the factor loading.

\begin{tabular}{|c|l|c|c|c|}
\hline S/No & Variable & No. of Items & Crobatch Alpha & Factor Loading \\
\hline 1 & Outlet Attributes & 5 & 0.8291 & 0.675 \\
\hline 2. & Demographic Attributes & 7 & 0.7563 & 0.6480 \\
\hline 3. & Product Attributes & 5 & 0.8000 & 0.6990 \\
\hline
\end{tabular}

\section{Source: SPSS Output}

The result shows that all the variables met the minimum threshold for acceptance since they are up to $70 \%(0.70)$, hence, reliable. The factor loading shows that the variables are valid since they are above $50 \%$. 
Collected data were analyzed using tables and simple percentages and multiple regression analysis at 0.05 level of significance using SPSS version 20.

The research model for this study is of the form:

$$
\mathrm{COBO}=\mathrm{f}(\mathrm{OT}, \mathrm{DA}, \mathrm{PA})
$$

Where:

COBO is Choice of Buying Outlet;

OT is Outlet Attributes

DA is Demographic Attributes

PA is Product Attributes.

The composition, direction and relative strength of each of the three independent variables on the single dependent variable (COBO) would be determined.

Decision Rules: We rejected the null hypotheses where the SPSS p-values were less than alpha (0.05) and the alternative hypotheses accepted.

\section{DATA PRESENTATION AND ANALYSIS}

Table 1: Questionnaire Distribution and Returns Rate

\begin{tabular}{|l|c|c|}
\hline Option & Frequency & Percentage \\
\hline Number of Copies Distributed & 272 & 100.00 \\
\hline Number of Copies Retrieved & 251 & 92.00 \\
\hline Number not Retrieved & 21 & 08.00 \\
\hline Number Valid for further analysis & 229 & 91.00 \\
\hline
\end{tabular}

Source: Field Survey, 2017

Table 1 shows that out of the 272 copies of the questionnaire distributed, 251 (92\%) copies were retrieved while 21 (8\%) copies were not retrieved. Out of the total copies retrieved, 229 $(91 \%)$ copies were found useful for further analyses. Therefore, further analyses were based on the 229 copies found valid.

Table 2: Respondents' Choice of Shopping Outlets

\begin{tabular}{|l|c|c|}
\hline Option & Frequency & Percentage \\
\hline Open Markets & 102 & 45.00 \\
\hline Supermarkets & 86 & 37.00 \\
\hline Petty Retail & 19 & 08.00 \\
\hline Hawkers & 22 & 10.00 \\
\hline Total & $\mathbf{2 2 9}$ & \\
\hline
\end{tabular}

Source: Field Survey, 2017

Table 2 shows that 102 (45\%) respondents, 86 (37\%) respondents, $19(8 \%)$ respondents and $22(10 \%)$ respondents do most of their shopping in open markets, supermarkets, petty retail outlets and from hawkers, respectively. 
Table 3: Respondents' Shopping Behaviour

\begin{tabular}{|c|c|c|c|c|c|c|}
\hline $\mathbf{S} / \mathbf{N}$ & Statement & SA & $\mathbf{A}$ & UN & D & SD \\
\hline (a) & $\begin{array}{l}\text { I shop regularly for grocery items and other } \\
\text { products. }\end{array}$ & 100 & 64 & 35 & 16 & 14 \\
\hline (b) & $\begin{array}{l}\text { There are available alternative shopping outlets } \\
\text { for the purchase of most products I require. }\end{array}$ & 103 & 73 & 15 & 26 & 12 \\
\hline (c) & $\begin{array}{l}\text { I always make my purchase decisions on the best } \\
\text { shopping outlet to buy my needed products. }\end{array}$ & 119 & 71 & 25 & 6 & 8 \\
\hline (d) & $\begin{array}{l}\text { In making this purchase decision, I consider a lot } \\
\text { of factors. }\end{array}$ & 108 & 74 & 24 & 14 & 9 \\
\hline (e) & $\begin{array}{l}\text { I consider the specific attributes of the available } \\
\text { outlets. }\end{array}$ & 76 & 98 & 42 & 14 & 12 \\
\hline (f) & $\begin{array}{l}\text { My personal characteristics influence my outlet } \\
\text { choice. }\end{array}$ & 79 & 82 & 42 & 14 & 12 \\
\hline \multirow[t]{3}{*}{ (g) } & $\begin{array}{l}\text { The attributes of the products to purchase are } \\
\text { key predictors of choice of buying point. }\end{array}$ & 91 & 85 & 34 & 11 & 8 \\
\hline & Total & 676 & 547 & 207 & 103 & 70 \\
\hline & Average (Percentage) & $\begin{array}{c}96 \\
(42 \%) \\
\end{array}$ & $\begin{array}{c}78 \\
(34 \%) \\
\end{array}$ & $\begin{array}{c}30 \\
(13 \%)\end{array}$ & $\begin{array}{c}15 \\
(7 \%)\end{array}$ & $\begin{array}{c}10 \\
(4 \%)\end{array}$ \\
\hline
\end{tabular}

Source: Field Survey, 2017

Table 3 above shows that on the average, 96 (42\%) respondents, 78 (34\%) respondents, 30 (13\%) respondents, 15 (7\%) respondents and 10 (4\%) respondents strongly agreed, agreed, had not decided, disagreed and strongly disagreed respectively on the statements relating to their shopping behaviour.

Table 4: Outlet Attributes

\begin{tabular}{|l|l|c|c|c|c|c|}
\hline S/N & Statement & SA & A & UN & D & SD \\
\hline (a) & I consider the location of an outlet. & 108 & 82 & 18 & 13 & 8 \\
\hline (b) & I consider nature of the outlet. & 92 & 79 & 26 & 18 & 14 \\
\hline (c) & I consider convenience in accessing the outlet & 102 & 85 & 24 & 9 & 9 \\
\hline (d) & I consider parking space. & 44 & 42 & 55 & 52 & 36 \\
\hline (e) & I consider quick shopping. & 97 & 71 & 24 & 23 & 14 \\
\hline & Total & $\mathbf{4 4 3}$ & $\mathbf{3 5 9}$ & $\mathbf{1 4 7}$ & $\mathbf{1 1 5}$ & $\mathbf{8 1}$ \\
\hline & Average & $\mathbf{8 9}$ & $\mathbf{7 1}$ & $\mathbf{2 9}$ & $\mathbf{2 3}$ & $\mathbf{1 6}(\mathbf{7 \%})$ \\
& & $\mathbf{( 3 9 \% )}$ & $\mathbf{( 3 1 \% )}$ & $(\mathbf{1 2 \% )}$ & $(\mathbf{1 0 \% )}$ & \\
\hline
\end{tabular}

Source: Field Survey, 2017

Table 4 shows that an average of 89 (39\%) respondents, 71 (31\%) respondents, 29 (12\%) respondents, $23(10 \%)$ respondents and 16 (7\%) respondents strongly agreed, agreed, had not decided, disagreed and strongly disagreed respectively on the effect of outlet attributes on their choice of shopping outlets. 
Table 5: Effect of Consumers' Demographics

\begin{tabular}{|l|l|c|c|c|c|c|}
\hline S/N & Statement & SA & A & UN & D & SD \\
\hline (a) & $\begin{array}{l}\text { My gender influences the choice of where I buy } \\
\text { my products. }\end{array}$ & 50 & 38 & 35 & 58 & 48 \\
\hline (b) & $\begin{array}{l}\text { My age influences the choice of where I buy } \\
\text { my products. }\end{array}$ & 22 & 42 & 36 & 66 & 63 \\
\hline (c) & $\begin{array}{l}\text { My income influences the choice of where I } \\
\text { buy my products. }\end{array}$ & 86 & 46 & 38 & 37 & 22 \\
\hline (d) & $\begin{array}{l}\text { My level of education influences the choice of } \\
\text { where I buy my products. }\end{array}$ & 65 & 43 & 49 & 43 & 29 \\
\hline (e) & $\begin{array}{l}\text { My marital status influences the choice of } \\
\text { where I buy my products. }\end{array}$ & 52 & 38 & 36 & 35 & 68 \\
\hline (f) & $\begin{array}{l}\text { My occupation influences the choice of where I } \\
\text { buy my products. }\end{array}$ & 43 & 42 & 24 & 46 & 74 \\
\hline (g) & $\begin{array}{l}\text { My family size influences the choice of where I } \\
\text { buy my products. }\end{array}$ & 76 & 46 & 31 & 48 & 28 \\
\hline Total & $\begin{array}{l}\text { Average } \\
\mathbf{3 9 4}\end{array}$ & $\begin{array}{c}\mathbf{5 6} \\
\mathbf{2 4 \% )}\end{array}$ & $\begin{array}{c}\mathbf{4 2} \\
\mathbf{( 1 8 \% )}\end{array}$ & $\begin{array}{c}\mathbf{3 6} \\
\mathbf{( 1 6 \% )}\end{array}$ & $\begin{array}{c}\mathbf{4 8} \\
\mathbf{( 2 1 \% )}\end{array}$ & $\mathbf{4 7}$ \\
$\mathbf{( 2 1 \% )}$ \\
\hline
\end{tabular}

\section{Source: Field Survey, 2017}

Table 5 shows that an average of 56 (24\%) respondents, 42 (18\%) respondents, 36 (16\%) respondents, 48 (21\%) respondents and 47 (21\%) respondents strongly agreed, agreed, had not decided, disagreed and strongly disagreed respectively on the effect of consumer demographics on their choice of shopping outlets.

Table 6: Effect of Product Attributes

\begin{tabular}{|c|c|c|c|c|c|c|}
\hline $\mathbf{S} / \mathbf{N}$ & Statement & SA & A & UN & D & SD \\
\hline (a) & $\begin{array}{l}\text { I consider the quality of the product in making } \\
\text { my purchase decision. }\end{array}$ & 98 & 70 & 30 & 18 & 13 \\
\hline (b) & $\begin{array}{l}\text { I consider the price of the product in making my } \\
\text { purchase decision. }\end{array}$ & 106 & 62 & 29 & 18 & 14 \\
\hline (c) & $\begin{array}{l}\text { I consider the assortment of the product in } \\
\text { making my purchase decision. }\end{array}$ & 61 & 107 & 40 & 12 & 9 \\
\hline (d) & $\begin{array}{l}\text { I consider the value of items in making my } \\
\text { purchase decision. }\end{array}$ & 94 & 77 & 26 & 19 & 13 \\
\hline \multirow[t]{3}{*}{ (e) } & $\begin{array}{l}\text { I consider after sales services in making my } \\
\text { purchase decision. }\end{array}$ & 82 & 78 & 28 & 23 & 18 \\
\hline & Total & 441 & 394 & 153 & 90 & 67 \\
\hline & Average & $\begin{array}{c}88 \\
(38 \%)\end{array}$ & $\begin{array}{c}79 \\
(34 \%)\end{array}$ & $\begin{array}{c}31 \\
(14 \%)\end{array}$ & $\begin{array}{c}18 \\
(8 \%)\end{array}$ & $\begin{array}{c}13 \\
(6 \%)\end{array}$ \\
\hline
\end{tabular}

Source: Field Survey, 2017

Table 6 shows that an average of 88 (38\%) respondents, 79 (34\%) respondents, 31 (14\%) respondents, $18(8 \%)$ respondents and $13(6 \%)$ respondents strongly agreed, agreed, had not decided, disagreed and strongly disagreed respectively on the effect of product attributes on their choice of shopping outlets.

Test of Hypothesis One

Model Summaryb

\begin{tabular}{|c|c|c|c|c|c|}
\hline Model & $\mathrm{R}$ & $\mathrm{R}$ Square & $\begin{array}{c}\text { Adjusted R } \\
\text { Square }\end{array}$ & $\begin{array}{c}\text { Std. Error of the } \\
\text { Estimate }\end{array}$ & Durbin-Watson \\
\hline 1 & $.981^{\mathrm{a}}$ & .963 & .962 & .21518 & .520 \\
\hline
\end{tabular}

a. Predictors: (Constant), Quick Shopping., Parking Space, Location, Convenience, Nature

b. Dependent Variable: Choice of Shopping Outlet 
ANOVA $^{a}$

\begin{tabular}{|ll|c|c|c|c|c|}
\hline & Model & Sum of Squares & df & Mean Square & F & Sig. \\
\hline \multirow{2}{*}{1} & Regression & 265.517 & 5 & 53.103 & 1146.854 & $.000^{\mathrm{b}}$ \\
& Residual & 10.326 & 223 & .046 & & \\
& Total & 275.843 & 228 & & & \\
\hline
\end{tabular}

a. Dependent Variable: Choice of Shopping Outlet

b. Predictors: (Constant), Quick Shopping., Parking Space, Location, Convenience, Nature

\begin{tabular}{|c|c|c|c|c|c|c|}
\hline \multicolumn{7}{|c|}{ Coefficients ${ }^{a}$} \\
\hline \multicolumn{2}{|r|}{ Model } & \multicolumn{2}{|c|}{ Unstandardized Coefficients } & \multirow{2}{*}{$\begin{array}{c}\begin{array}{c}\text { Standardized } \\
\text { Coefficients }\end{array} \\
\text { Beta } \\
\end{array}$} & \multirow[t]{2}{*}{$\mathrm{t}$} & \multirow[t]{2}{*}{ Sig. } \\
\hline & & B & Std. Error & & & \\
\hline \multirow{6}{*}{1} & (Constant) & .143 & .072 & & 1.985 & .048 \\
\hline & Location & .148 & .051 & .139 & 2.895 & .004 \\
\hline & Nature & .359 & .072 & .384 & 4.983 & .000 \\
\hline & Convenience & .195 & .061 & .178 & 3.206 & .002 \\
\hline & Parking Space & .000 & .021 & .001 & .023 & .982 \\
\hline & Quick Shopping. & .266 & .066 & .295 & 4.054 & .000 \\
\hline
\end{tabular}

a. Dependent Variable: Choice of Shopping Outlet

Result shows that location, nature of outlet, convenience access to outlet and quick shopping are significant predictors of choice of shopping outlet, while parking space is not a significant predictor.

\section{Hypotheses Two}

Model Summaryb

\begin{tabular}{|c|c|c|c|c|c|}
\hline Model & $\mathrm{R}$ & $\mathrm{R}$ Square & $\begin{array}{c}\text { Adjusted R } \\
\text { Square }\end{array}$ & $\begin{array}{c}\text { Std. Error of the } \\
\text { Estimate }\end{array}$ & Durbin-Watson \\
\hline 1 & $.939 \mathrm{a}$ & .881 & .877 & .38562 & .243 \\
\hline
\end{tabular}

a. Predictors: (Constant), Family Size, Age, Income, Occupation, Gender, Education, Marital Status

b. Dependent Variable: Choice of Shopping Outlet

ANOVAa $^{a}$

\begin{tabular}{|ll|c|c|c|c|c|}
\hline & Model & Sum of Squares & Df & Mean Square & F & Sig. \\
\hline \multirow{2}{*}{1} & Regression & 242.979 & 7 & 34.711 & 233.425 & $.000^{\mathrm{b}}$ \\
& Residual & 32.864 & 221 & .149 & & \\
& Total & 275.843 & 228 & & & \\
\hline
\end{tabular}

a. Dependent Variable: Choice of Shopping Outlet

b. Predictors: (Constant), Family Size, Age, Income, Occupation, Gender, Education, Marital Status. 
Coefficients $^{\mathbf{a}}$

\begin{tabular}{|l|c|c|c|c|c|}
\hline \multirow{2}{*}{ Model } & \multicolumn{2}{|c|}{ Unstandardized Coefficients } & $\begin{array}{c}\text { Standardized } \\
\text { Coefficients }\end{array}$ & \multirow{2}{*}{ Sig. } \\
\cline { 2 - 5 } & B & Std. Error & Beta & & \\
\hline \multirow{2}{*}{ (Constant) } & 1.186 & .083 & & 14.316 & .000 \\
Gender & .429 & .087 & .571 & 4.924 & .000 \\
Age & .177 & .075 & .213 & 2.350 & .020 \\
Income & .478 & .078 & .640 & 6.126 & .000 \\
Education & .364 & .095 & .459 & 3.839 & .000 \\
Marital Status & -.561 & .102 & -.792 & -5.529 & .000 \\
Occupation & -.313 & .078 & -.439 & -4.012 & .000 \\
Family Size & .206 & .089 & .265 & 2.317 & .021 \\
\hline
\end{tabular}

a. Dependent Variable: Choice of Shopping Outlet

All the predictors (family size, age, income, occupation, gender, education and marital status) are significant predictors of choice of shopping outlet since their sig(p-values) fall within the acceptance region (less than alpha, 0.05).

\section{Hypothesis Three}

Model Summaryb

\begin{tabular}{|c|c|c|c|c|c|}
\hline Model & $\mathrm{R}$ & $\mathrm{R}$ Square & $\begin{array}{c}\text { Adjusted R } \\
\text { Square }\end{array}$ & $\begin{array}{c}\text { Std. Error of the } \\
\text { Estimate }\end{array}$ & Durbin-Watson \\
\hline 1 & $.981^{\mathrm{a}}$ & .963 & .962 & .21457 & .591 \\
\hline
\end{tabular}

a. Predictors: (Constant), Value, Assortment, Price, Quality

b. Dependent Variable: Choice of Shopping Outlet

ANOVA ${ }^{\mathrm{a}}$

\begin{tabular}{|ll|c|c|c|c|c|}
\hline & Model & Sum of Squares & df & Mean Square & F & Sig. \\
\hline \multirow{2}{*}{1} & Regression & 265.530 & 4 & 66.383 & 1441.898 & $.000^{\mathrm{b}}$ \\
& Residual & 10.313 & 224 & .046 & & \\
& Total & 275.843 & 228 & & & \\
\hline
\end{tabular}

a. Dependent Variable: Choice of Shopping Outlet

b. Predictors: (Constant), Value, Assortment, Price, Quality

Coefficients ${ }^{\mathbf{a}}$

\begin{tabular}{|c|c|c|c|c|c|c|}
\hline & \multirow[t]{2}{*}{ Model } & \multicolumn{2}{|c|}{ Unstandardized Coefficients } & \multirow{2}{*}{$\begin{array}{c}\begin{array}{c}\text { Standardized } \\
\text { Coefficients }\end{array} \\
\text { Beta }\end{array}$} & \multirow[t]{2}{*}{$\mathrm{t}$} & \multirow[t]{2}{*}{ Sig. } \\
\hline & & $\mathrm{B}$ & Std. Error & & & \\
\hline \multirow{5}{*}{1} & (Constant) & .267 & .058 & & 4.621 & .000 \\
\hline & Quality & .348 & .098 & .373 & 3.552 & .000 \\
\hline & Price & -.087 & .069 & -.095 & -1.252 & .212 \\
\hline & Assortment & .143 & .038 & .130 & 3.802 & .000 \\
\hline & Value & .548 & .078 & .583 & 7.029 & .000 \\
\hline
\end{tabular}

Quality, assortment, value and after sales services are significant predictors of choice of shopping outlet, while price ( $p$-value; 0.212 ) is not a significant predictors

Table 7: Summary of Test of Hypotheses

\begin{tabular}{|l|l|l|l|l|l|}
\hline S/N & Description & P-Value & R Value & Alpha & Decision \\
\hline 1 & Hypothesis One & 0.000 & 0.939 & 0.05 & Reject Null \\
\hline 2 & Hypothesis Two & 0.000 & 0.981 & 0.05 & Reject Null \\
\hline 3 & Hypothesis Three & 0.000 & 0.981 & 0.05 & Reject Null \\
\hline
\end{tabular}




\section{DISCUSSION OF FINDINGS}

It was revealed that there is significant relationship between outlet attributes and choice of buying outlet. That is, location, nature of outlet, convenience access to outlet and quick shopping are significant predictors of choice of shopping outlet. These are in line with the findings of Akinci et al. (2007), Sinha and Banerjee (2004), Oghojafor Chen \& Quester (2006) and Sirdesh-mukh et al. (2002). However, the study revealed that parking space is not a significant predictor of choice of shopping outlet. This contradicts the studies of Sinha and Banerjee (2004), Oghojafor Chen \& Quester (2006) who respectively found parking space in their various studies to be one of the predictors of choice of shopping outlet.

Also, it was discovered that there is significant relationship between demographic attributes (family size, age, income, occupation, gender, education and marital status) and choice of buying outlet. This is in agreement with the findings of Yalcin (2005) who found out that such demographic factors as age, occupation and number of children affect supermarket loyalty.

On the product attributes, the study revealed that there is significant relationship between product attributes and choice of buying outlet. In other words, product quality, assortment, value and after sales services are factors which influence consumers' choice of shopping outlet. This supports the findings of Duman and Yagci (2006), Akinci et al. (2007), Miranda, Konya \& Havrila (2005), Oghojafor, et al (2012), (Tuli \& Mookerjee, 2004), Ling, Choo, \& Pysarchik (2004) and Yilmaz et al., (2007).

Nevertheless, the test revealed that price is not a significant predictor of consumers' choice of shopping outlet. However, this result is against the findings of Duman and Yagci (2006), Akinci et al. (2007), Miranda, Konya \& Havrila (2005), Oghojafor, et al (2012), (Tuli \& Mookerjee, 2004), Ling, Choo, \& Pysarchik (2004) and Yilmaz et al. (2007) who found price in their respective studies as one of the predictors of choice of shopping outlet.

\section{CONCLUSION}

With the recent changes in the Nigerian economy and general business/marketing environment; the evolving nature of retailing and its various firms; and the consequent competitiveness in the sector, consumers are faced with many challenges in determining their choice of shopping outlets. In order to make wise choices, consumers consider various factors ranging from outlet attributes, demographic attributes to product attributes. Thus, the location of an outlet, its nature, convenience, quick shopping, product quality, assortment, value, after sales services, family size, age, income, occupation, gender, education and marital status have been found to be significant predictors of consumers' choice of shopping outlets.

\section{RECOMMENDATIONS}

Based on the findings of this study, the following recommendations are put forward by the researcher:

1. Shop owners and managers of shopping outlets are encouraged to adequately consider the following factors:

i. Outlet attributes which consist of location of an outlet, its nature, convenience and quick shopping.

ii. Product attributes which consist of product quality, assortment, value, and after sales services.

iii. Demographic Attributes which consist of family size, age, income, occupation, gender, education and marital status 
2. Although our findings revealed that parking space and price are not significant predictors of choice of shopping outlets, outlets that combine the significant variables listed above with competitive pricing strategy and convenient parking spaces would have more competitive advantage than others.

3. For effective management of drivers of outlet choice among consumers, owners of shopping outlets are encouraged to consider the adoption of the conceptual model of drivers of choice of outlet proposed by the researchers.

\section{References}

Abdullah, R., Ismail, N., Abdul Rahman, A.F., Mohd Suhaimin, M., Safie, S.K., Mohd Tajuddin, M. T. H., Noor Armia, R., Nik Mat, N.A., Derani, N., Samsudin, M.M., Adli Zain, R. \& Sekharan Nair, G.K. (2012). The Relationship between Store Brand and Customer Loyalty in Retailing in Malaysia. Asian Social Science, 8(2), 171-184.

Akinci, E. D.,Bacanli, S.,Kiro glu, G.(2007).Adaptive Conjoint Analysis and Application on Istanbul Discount Markets. Journal of Dogus University,8,1-11.

Batra, R. \& Sinha, I. (2000). Consumer-level factors moderating the success of private label brands. Journal of Retailing, 76(2), 175-191.

Beldona, S. \& Wysong, S. (2007). Putting the "Brand" back into store brands: An exploratory examination of store brands and brand personality. Journal of Product \& Brand Management, 16(4), 226-235.

Bettman, J.R. (1973). Perceived price and product perceptual variables. Journal of Marketing Research, 10(1), 100102.

Bloemer, J. \& Ruyter, K. D. (1998). On the relationship between store image, store satisfaction and store loyalty. European Journal of Marketing, 32,499-513.

Chen, S. C. \& Quester, G. (2006). Modeling store loyalty: Perceived value in market orientation practice. Journal of Services Marketing, 20,188-198.

Cochran, W. G. (1963). Sampling Techniques, 2nd Ed., New York: John Wiley and Sons, Inc.

Cronin, J., Joseph, Jr , Brady, M. K.,Hult, G \& Tomas, M. (2000). Assessing the effect of quality, value and customer satisfaction on consumer behavioral intentions in service environments. Journal of Retailing,76,193-218.

Davis, J. (2008). Selling wares on the streets of Accra: A case study of street hawkers in Ghana's capital. FOCUS on Geography 51(3): 32-36.

Dick, A. S., \& Basu, K. (1994). Customer loyalty: Towards an integrated framework. Journal of the Academy of Marketing Science, 22, 99-113.

Duman, T. \& Yagci, M. İ. (2006). On factors affecting continuous purchase intentions of supermarket customers: An attempt at modeling. METU Studies Development, 33, 87-116.

Field, S., O. Masakure and S. Henson. 2010. Rethinking localization-a low-income country perspective: the case of Asian vegetables in Ghana. Cambridge Journal of Regions, Economy and Society 3(2):261-277.

Grace, D., O"cass, A. (2005). An examination of the antecedents of repatronage intentions across different retail store formats. Journal of Retailing and Consumer Services, 12,227-243

Grewal, D., Krishnan, R., Baker, J., \& Borin, N. (1998). The effect of store name, brand name and price discounts on consumers' evaluations and purchase intentions. Journal of Retailing, 74, 331-352.

Gwin, C F. \& Gwin, C, R. (2003). Product attributes model: A tool for evaluating brand positioning. Journal of Marketing Theory and Practice, 11(2), 30-42.

Hoch, S.J. \& Banerji, S. (1993). When do private labels succeed? Sloan Management Review, 34(4), 57-67.

Jin, B \& Kim, J (2003). A typology of Korean discount shoppers: Shopping motives, store attributes and outcomes. International Journal of Service Industry Management. 14(4), 396-419.

Jin, B. \& Suh, Y.G. (2005). Integrating effect of consumer perception factors in predicting private brand purchase in Korean discount store context. Journal of Consumer Marketing, 22(2), 62-71.

Johnson, P.N. T., and Yawson, R. M. (2000). Enhancing the food security of the peri-urban and urban poor through improvements to the quality, safety and economics of street-vended foods. Report on Workshop for

"Stakeholders, Policy makers and regulators of Street food vending in Accra," Miklin Hotel, Accra, Sept 25-26. 
Kremer, F. \& Viot, C. (2012). How store brands build retailer brand image. International Journal of Retail \& Distribution Management, 40(7), 528-543.

Ling, S., Choo, H. J., Pysarchik, D. T (2004): "Adopters of new food products in India". Marketing Intelligence \& Planning, Vol. 22 Iss: 4, pp.371 - 391 DOI: 10.1108/02634500410542743

Miranda, M. J.,Kónya, L. \& Havrila, I.(2005). Shoppers' satisfaction levels are not the only key to store loyalty. Marketing Intelligence and Planning, 23,220-232.

Neven, D., T. Reardon, J. Chege and H. Wang. 2006. Supermarkets and consumers in Africa: the case of Nairobi, Kenya. Journal of International Food \& Agribusiness Marketing 18(1-2):103-123.

Oghojafor, B.E.A., Ladipo, P.K.A., \& Nwagwu, K.O(2012). Outlet Attributes as Determinants of Preference of Women between a Supermarket and a Traditional Open Market. American Journal of Business and Management Vol. 1, No. 4, 2012, 230-240

Polat, C., Kulter, B. (2007). The factors that affect the retail store preferences of consumers: an application on the consumers in Niğde. 12th National Marketing Conference, Sakarya, Turkey.

Rani, P. (2014) Factors influencing consumer behaviour. International Journal of Current Reserves, 2014, 2(9):5262.

Reardon, T., P. Timmer and J. Berdegue. 2004. The rapid rise of supermarkets in developing countries: induced organizational, institutional, and technological change in agrifood systems. Electronic Journal of Agricultural and Development Economics 1(2):168-183.

Richardson, P.S., Dick, A.S. \& Jain, A.K. (1994). Extrinsic and intrinsic cue effects on perceptions of store brand quality. Journal of Marketing, 58, 28-36.

Richardson, P.S., Jain, A.K., \& Dick, A. (1996). Household store brand proneness: A framework. Journal of Retailing, 72(2), 159-185.

Semeijn, J., Van Riel, A.C.R. \& Ambrosini, A.B. (2004).Consumer evaluations of store brands: Effects of store image and product attributes. Journal of Retailing and Consumer Services, 11.247-258.

Sethuraman, R. \& Cole, C. (1999). Factors influencing the price premiums that consumers pay for national brands over store brands. Journal of Product \& Brand Management, 8(4), 340-351.

Sinha, P K, \& Banerjee, A. (2004). Store choice behaviour in an evolving market. International Journal of Retail and Distribution Management, 32(10),.482-494. http://dx.doi.org/10.1108/09590550410558626

Sirdeshmukh, D.,Singh, J. \& Sabol, B.(2002). Consumer trust, value and loyalty in relational exchanges. Journal of Marketing, 66,15-37.

Toh, P. S. and A. Birchenough. 2000. Food safety knowledge and attitudes: culture and environment impact on hawkers in Malaysia. Knowledge and attitudes are key attributes of concern in hawker food handling practices and outbreaks of food poisoning and their prevention. Food Control 11(6):447-452.

Tuli, R. \& Mookerjee, A. (2004). Retail formats: Patronage behavior of Indian rural consumers. South Asian Journal of Management; 11(3),57-73.

Uslu, S. (2005). The reasons for shopping mall preferences of consumers. Marketing World,19,54-63.

Uusitalo, 0 (2001). Consumer perceptions of grocery retail formats and brands. International Journal of Retail and Distribution Management,29(5),214-225. http://dx.doi.org/10.1108/09590550110390995

Yalcin, A. M. (2005). The effect of consumer demographic characteristics on store loyalty Intentions. Journal of Institute of Business Administration-Management, 16,104-115.

Yeniceri, T. \& Erten, E.(2008). Analyzing the relationships among perceptions on store loyalty programs, trust, customer commitment to the relationship and store loyalty through structural equation modeling. Dogus University Journal, 9, 232-247.

Yilmaz, V., Aktas, C. \& Celik, H. E. (2007). Development of a Scale for measuring consumer behaviour in store choice. Anadolu, University Journal of Social Sciences, 7, 171-185. 